OPEN ACCESS

Edited by:

Gen He,

Ocean University of China, China

Reviewed by:

Anderson O. L. Wong

The University of Hong Kong,

Hong Kong

Chunyang Zhang,

Harvard Medical School,

United States

${ }^{*}$ Correspondence:

Encarnación Capilla ecapilla@ub.edu

Specialty section:

This article was submitted to Experimental Endocrinology,

a section of the journal

Frontiers in Endocrinology

Received: 27 November 2018 Accepted: 01 March 2019 Published: 22 March 2019

Citation: Balbuena-Pecino S, Riera-Heredia N

Vélez EJ, Gutiérrez J, Navarro I, Riera-Codina M and Capilla E (2019) Temperature Affects Musculoskeletal

Development and Muscle Lipid Metabolism of Gilthead Sea Bream (Sparus aurata).

Front. Endocrinol. 10:173. doi: 10.3389/fendo.2019.00173

\section{Temperature Affects Musculoskeletal Development and Muscle Lipid Metabolism of Gilthead Sea Bream (Sparus aurata)}

\section{Sara Balbuena-Pecino, Natàlia Riera-Heredia, Emilio J. Vélez, Joaquim Gutiérrez, Isabel Navarro, Miquel Riera-Codina and Encarnación Capilla*}

Departament de Biologia Cel.Iular, Fisiologia i Immunologia, Facultat de Biologia, Universitat de Barcelona, Barcelona, Spain

World population is expected to increase to approximately 9 thousand million people by 2050 with a consequent food security decline. Besides, climate change is a major challenge that humanity is facing, with a predicted rise in mean sea surface temperature of more than $2^{\circ} \mathrm{C}$ during this century. This study aims to determine whether a rearing temperature of 19,24 , or $28^{\circ} \mathrm{C}$ may influence musculoskeletal development and muscle lipid metabolism in gilthead sea bream juveniles. The expression of growth hormone (GH)/insulin-like growth factors (IGFs) system-, osteogenic-, myogenic-, and lipid metabolism-related genes in bone and/or white muscle of treated fish, and the in vitro viability, mineralization, and osteogenic genes expression in primary cultured cells derived from bone of the same fish were analyzed. The highest temperature significantly down-regulated igf-1, igf-2, the receptor igf-1ra, and the binding proteins igfbp-4 and igfbp-5b in bone, and in muscle, igf-1 and igf-1ra, suggesting impaired musculoskeletal development. Concerning myogenic factors expression, contrary responses were observed, since the increase to $24^{\circ} \mathrm{C}$ significantly down-regulated myod 1 and mrf4, while at $28^{\circ} \mathrm{C}$ myod2 and myogenin were significantly up-regulated. Moreover, in the muscle tissue, the expression of the fatty acid transporters cd36 and fabp11, and the lipases lipa and Ipl-Ik resulted significantly increased at elevated temperatures, whereas $\beta$-oxidation markers cpt1a and cpt1b were significantly reduced. Regarding the primary cultured bone-derived cells, a significant up-regulation of the extracellular matrix proteins on, op, and ocn expression was found with increased temperatures, together with a gradual decrease in mineralization along with fish rearing temperature. Overall, these results suggest that increasing water temperature in this species appears to induce unfavorable growth and development of bone and muscle, through modulating the expression of different members of the GH/IGFs axis, myogenic and osteogenic genes, while accelerating the utilization of lipids as an energy source, although less efficiently than at optimal temperatures.

Keywords: thermal exposure, bone cells, white muscle, mineralization, GH/IGFs system, lipid catabolism 


\section{INTRODUCTION}

Nowadays, society is facing one of the greatest world challenges: how to feed 9 thousand million people by 2050 in the context of global change and economic and financial uncertainty $(1,2)$. In this situation, aquaculture has a relevant role, satisfying the growing need of fish, and gilthead sea bream (Sparus aurata, L.) has become over the last 30 years one of the most important fish species farmed in the Mediterranean area (3). Besides food insecurity, climate change is also a major global challenge that concerns humanity. Warming of the climate system is unequivocal and particularly relevant for this study, the mean sea surface temperature may increase more than $2^{\circ} \mathrm{C}$ by the end of this century (4). Increased water temperature is known to directly influence several biochemical and physiological processes in ectothermic fish (5), including growth or metabolic rate (6).

Temperature can influence the growth hormone (GH)/insulin-like growth factors (IGFs) system, the main endocrine axis controlling growth in vertebrates. Previous studies have reported a link between environmental temperature and plasma levels of IGF-1 and GH, independently of the nutritional status $(7,8)$. The GH/IGFs system includes peptides (IGF-1 and IGF-2), IGF-1 receptors (IGF-1Ra and IGF-1Rb), as well as is composed of six IGF binding proteins (IGFBPs) that can exert different effects on IGFs function depending on the cellular context $(9,10)$. Interestingly, IGFBP-2 in teleosts is the main circulatory binding protein and shows a physiological regulation similar to the most relevant one in mammals, IGFBP-3 (11). Furthermore, elevated temperatures, along with other risk factors such as mineral and vitamin deficiencies, light regimes or fast growth, have been linked in fish with increased occurrence of skeletal anomalies (12). In fact, fast muscle growth can exert high mechanical pressure on the developing bone, hence, synchronicity between bone and muscle growth is required for proper musculoskeletal development [reviewed by Ytteborg et al. (13)]. The higher prevalence of vertebral deformities as a result of increased temperature during the early stages of development has been documented in gilthead sea bream (14), as well as in other species including Solea senegalensis (15), Salmo salar (16), or Dicentrarchus labrax (17). In the case of Sparids, the presence of abnormalities is more evident in larvae reared below $15^{\circ} \mathrm{C}$ and above $22^{\circ} \mathrm{C}$ (18), and recent studies have demonstrated in this species that thermal imprinting during embryogenesis causes long-term effects on bone physiology $(19,20)$. In this sense, the increase in temperature can be recognized as one important problem for aquaculture and animal welfare in a global climate change context.

Cellular and molecular mechanisms for musculoskeletal development in teleost fish have been demonstrated to be similar than in mammals. Osteoblasts, as well as myocytes, arise from mesenchymal stem cells (MSCs), precursor cells that are also able to differentiate into other cell types like chondroblasts or adipocytes after the coordinated induction of key transcription factors expression. Recently, morphological and molecular characterization of a bone-derived cell culture of gilthead sea bream has been reported $(20,21)$, and the ability of those MSCs to differentiate into other cell types such as adipocyte-like cells has been demonstrated (22). However, these multipotent cells have not been deeply characterized at a structural/functional level. Concerning the main regulators of bone development at a transcriptional level, Runt-related transcription factor 2 (Runx2) is the one required for commitment toward the osteogenic lineage. Afterwards, osteoblasts express molecules of the extracellular matrix (ECM), which include structural fibers as collagen or fibronectin but also non-collagenous proteins that regulate mineralization of the ECM such as osteonectin $(\mathrm{ON})$, osteopontin (OP), and osteocalcin (OCN) (20). In the case of muscle, abundant studies using a satellite cell model system have properly characterized the process of myogenesis in gilthead sea bream (23). The coordinated expression of myogenic regulatory factors (MRFs) is also required for myogenesis to properly occur. Among these transcription factors, Myf5 and MyoD are involved in myocytes activation and proliferation, whereas Myogenin and MRF4 act later allowing myotube formation and maturation (24).

In addition to growth, increased water temperature is also known to directly affect energy demand in ectotherms, and consequently to exert an impact in lipid metabolism and the use of fat depots (25). Lipids are an important energy source for fish skeletal muscle. Lipases such as lipoprotein lipase (LPL) and lipase A (LIPA) can provide fatty acids from triglycerides circulating in the form of chylomicrons and very low-density lipoproteins. Then, fatty acid transporters such as CD36 and FATP1, which are nutritionally and hormonally regulated in fish muscle $(26,27)$, facilitate the entry of these fatty acids into the cell. Endogenous stored triglycerides, when necessary, can also be hydrolyzed by other lipases as the hormone-sensitive lipase (HSL). Then, non-esterified fatty acids undergo $\beta$-oxidation in the mitochondrial matrix (28).

In this framework, the aim of the present study was to evaluate the effects of three increasing rearing temperatures $(19,24$, and $28^{\circ} \mathrm{C}$ ) in gilthead sea bream juveniles through an in vivo/in vitro approach. First, the in vivo expression of GH/IGFs axis-, osteogenic-, myogenic- and lipid metabolism-related genes in bone and/or white muscle was determined, and then, the in vitro development and expression of osteogenic genes in primary cultured bone-derived cells. All this performed to extend the knowledge of the possible impacts of global climate change on musculoskeletal growth and the physiology in this important aquaculture marine species.

\section{MATERIALS AND METHODS}

\section{Animals and Experimental Trial}

Gilthead sea bream juveniles (50 g body weight), were obtained from Piscimar fish farm (Andromeda Group, Burriana, Spain) and maintained at the animal facilities of the Faculty of Biology at the University of Barcelona (Spain). After 2 weeks acclimation period, fish were randomly distributed into three $200 \mathrm{~L}$ glass tanks (11 fish per tank and condition) under a $12 \mathrm{~h}$ light $/ 12 \mathrm{~h}$ dark photoperiod, at room temperature $\left(19 \pm 1^{\circ} \mathrm{C}\right)$. The experiment was performed in January. Fish were daily fed ad libitum twice with a commercial diet (Skretting, Burgos, Spain). At the beginning of the trial, all three tanks started at the same temperature of $19^{\circ} \mathrm{C}$ and then, two of them went from 19 to $24^{\circ} \mathrm{C}$ 
or $28^{\circ} \mathrm{C}$, with a rate of $\Delta 1^{\circ} \mathrm{C}$ each day following the protocol of Hevrøy et al. (6) with a $250 \mathrm{~W}$ thermostatic heater (EHEIM, Deizisau, Germany). Once the water temperature required was achieved, fish were held for 3 more days and sampled on the day fourth. A schema of the experimental trial is shown in Figure 1. The temperature of the tanks was registered with a precision thermometer (Sera ${ }^{\circledR}$ ) three times a day to ensure the corresponding temperature was maintained. Before sampling, fish were fasted for $24 \mathrm{~h}$ and then were anesthetized (MS-222 $150 \mathrm{mg} / \mathrm{L}$ ) and subsequently sacrificed by a blow to the head. Samples of white muscle and vertebral bone were collected and immediately frozen in liquid nitrogen and stored at $-80^{\circ} \mathrm{C}$ until further analyses, and small fragments of bone were also used to perform the primary cultures just after sampling as explained in section Primary Culture of Bone-Derived Cells.

All animal handling procedures were approved by the Ethics and Animal Care Committee of the University of Barcelona, in accordance with the guidelines of the European Union Council (86/609/EU), and the Spanish and Catalan Government assigned principles and legislation (permit numbers DAAM 6759 and 9336 for the in vitro and in vivo experiments, respectively).

\section{Primary Culture of Bone-Derived Cells}

Bone fragments of 10 fish per temperature condition were used per culture, each one considered an independent replicate, following the protocol of Capilla et al. (21). Briefly, the vertebras were removed, cleaned of all adherent tissues and washed twice in phosphate buffered saline with $1 \%$ antibiotic/antimycotic solution (A/A) prior to manually obtain with a scalpel small $(<1 \mathrm{~mm})$ fragments. After that, two digestions of 30 and $90 \mathrm{~min}$, respectively, were done with $0.125 \%$ Type II collagenase in Hank's balanced salt solution at $18^{\circ} \mathrm{C}$ with gentle agitation. Next, the fragments were washed twice with Dulbecco's Modified Eagle Medium (DMEM) supplemented with 1\% A/A solution

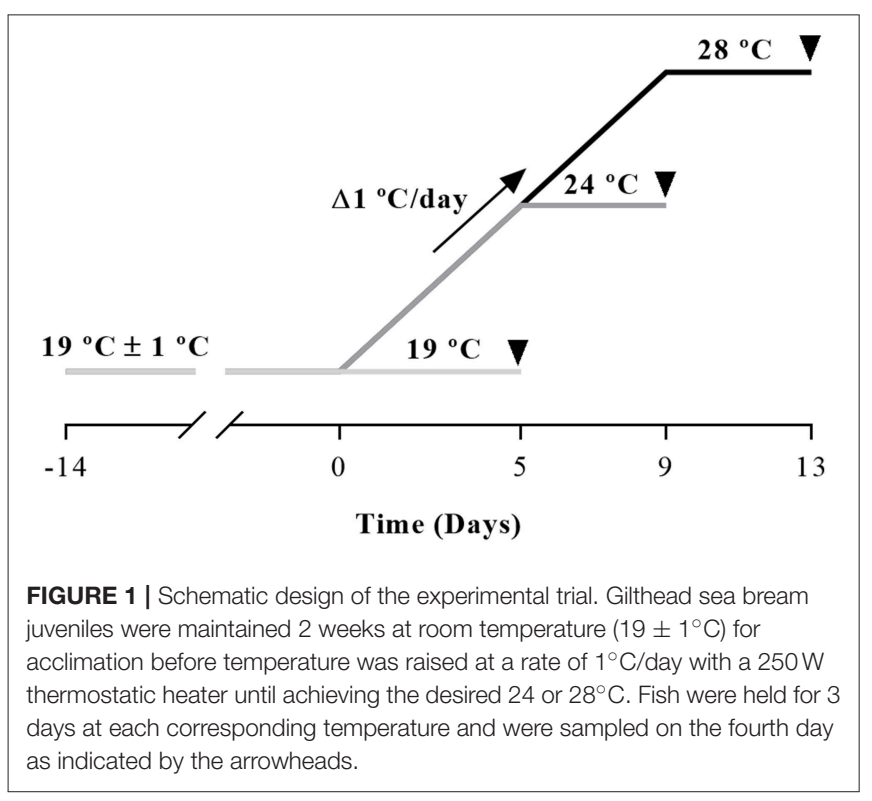

and finally cultured in complete growth medium composed of DMEM supplemented with $10 \%$ fetal bovine serum and $1 \%$ A/A solution. Cells were seeded into 6 or 12 -well plates and incubated at $23^{\circ} \mathrm{C}$ and $2.5 \% \mathrm{CO}_{2}$. Medium was changed every 2 days. As indicated in the following sections, the fragments were removed from the plates at different days after seeding in order to perform the corresponding assays with the cells attached. To investigate whether temperature could affect the phenotype and differentiation of bone-derived cells in culture, pictures at days 8 and 15 of development were taken with a Canon EOS 1000D digital camera. All cell-culture reagents were purchased from Sigma-Aldrich (Tres Cantos, Spain) and all plastic items were obtained from Nunc (Labclinics, Barcelona, Spain).

\section{Viability Assay}

The methylthiazolyldiphenyl-tetrazolium bromide (MTT) assay was used to evaluate cell viability as previously done in gilthead sea bream bone cells (21) and muscle cells (29). This method was selected since comparative studies of different viability assays regularly used revealed that it is the most sensitive one in terms of detecting cytotoxicity (30). Briefly, on days 8 and 15 cell samples of two duplicate wells of the 12 well-plates were incubated for $3 \mathrm{~h}$ in DMEM with a final concentration of $5 \mathrm{mg} / \mathrm{mL}$ of MTT (SigmaAldrich). Then, cells were washed with phosphate buffered saline and resuspended in $150 \mu \mathrm{L}$ of dimethyl sulfoxide (DMSO) per well. The viability values were obtained from the absorbance measured at $570 \mathrm{~nm}$ in duplicate 96-wells, with correction at $650 \mathrm{~nm}$, using a microplate reader (Tecan Infinite 200). Data from day 15 cells are presented as fold change relative to each corresponding day 8 of culture $(n=10)$.

\section{Mineralization Assay}

Culture differentiation was evaluated according to mineralization of the ECM. The deposition of minerals was analyzed in day 20 cultured cells by alizarin red S (ARS) staining, following the protocol of Capilla et al. (21). Cells were fixed for $15 \mathrm{~min}$ with $10 \%$ formalin and stained with $2 \%$ ARS ( $\mathrm{pH} 4.1-4.3)$ during $20 \mathrm{~min}$. After washing excessive dye with water, quantification of the staining was done by means of acid extraction of the ARS stain with $10 \%$ acetic acid. The monolayer was then scrapped and transferred to a $1.5 \mathrm{ml}$ tube. After vortex, the slurry was overlaid with mineral oil (Sigma-Aldrich), heated to $85^{\circ} \mathrm{C}$ for $10 \mathrm{~min}$, cooled on ice and centrifuged at $16,000 \mathrm{~g}$ for $15 \mathrm{~min}$. At this point, $10 \%$ ammonium hydroxide was added to the supernatant to neutralize the acid and finally, aliquots of the different samples were read at $405 \mathrm{~nm}$ in duplicate 96-wells, using a microplate reader (Tecan Infinite 200). Data are presented as optical density arbitrary units $(n=10)$.

\section{Gene Expression Analyses RNA Extraction and cDNA Synthesis}

Total RNA was extracted from $\sim 100 \mathrm{mg}$ of vertebral bone and white muscle tissues, or from cell samples of two duplicate wells of the 6 well-plates at day 15 with $1 \mathrm{~mL}$ of TRI Reagent Solution (Applied Biosystems, Alcobendas, Spain) following the manufacturer's instructions. Total concentration and purity were determined using a NanoDrop 2000 (Thermo Scientific, 
Alcobendas, Spain), and integrity of the different samples was confirmed in a $1 \%$ agarose gel $(\mathrm{w} / \mathrm{v})$ stained with SYBR-Safe DNA Gel Stain (Life Technologies, Alcobendas, Spain). Next, 1,000 ng of total RNA were treated with DNase I (Life Technologies) to remove all genomic DNA, and reverse transcribed with the Transcriptor First Strand cDNA Synthesis Kit (Roche, Sant Cugat del Valles, Spain). The cDNA obtained was stored at $-20^{\circ} \mathrm{C}$ for real-time quantitative PCR analyses (qPCR).

\section{Real-Time Quantitative PCR}

The mRNA transcript levels of the target genes plus three reference genes were examined in a CFX $384^{\mathrm{TM}}$ real-time system (Bio-Rad, El Prat de Llobregat, Spain). All the analyses were performed in triplicate wells using 384-well plates with $2.5 \mu \mathrm{L}$ of iTaq Universal SYBR Green Supermix (Bio-Rad), $250 \mathrm{nM}$ final concentration of forward and reverse primers (Table 1) and 1 $\mu \mathrm{L}$ of diluted cDNA for each sample, in a final volume of $5 \mu \mathrm{L}$. As described before $(31,32)$, reactions were performed with an initial activation step of $3 \mathrm{~min}$ at $95^{\circ} \mathrm{C}, 40$ cycles of $10 \mathrm{~s}$ at $95^{\circ} \mathrm{C}$ and $30 \mathrm{~s}$ at $55-68^{\circ} \mathrm{C}$ (primer-dependent, see Table 1) followed by an amplicon dissociation analysis from 55 to $95^{\circ} \mathrm{C}$ at $0.5^{\circ} \mathrm{C}$ increase each $30 \mathrm{~s}$. Before the analyses, a dilution curve with a pool of samples was run to confirm primer efficiency, specificity of the reaction, absence of primer-dimers, and to determine the appropriate cDNA dilution for each assay. Negative controls [no template control (NTC), no reverse transcriptase control (RTC) and MilliQ water (PCR)] were included and run in duplicate. The expression level of each target gene analyzed was calculated using the Pfaffl method (33), relative to the geometric mean of the two most stable reference genes determined for each tissue by the geNorm algorithm, both implemented in the Bio-Rad CFX manager 3.1. software.

\section{Statistical Analysis}

Data were analyzed using IBM SPSS Statistics v. 22 (IBM, Armonk, USA) and are presented as Mean \pm SEM. Data normality and homoscedasticity were tested among temperature groups using Shapiro-Wilk and Levene's tests, respectively. Statistical significance was assessed by one-way analysis of variance (one-way ANOVA) followed by Tukey's post-hoc test. When homoscedasticity was not observed Dunnett T3 test was applied. Statistical differences were considered significant for all analysis when $p<0.05$.

\section{RESULTS}

\section{HSPs and Proliferation Marker Genes Expression in Bone and White Muscle Tissues}

In bone, heat shock proteins, $h s p 30$ and $h s p 90 b$ mRNA levels were similar among the three groups (Figure 2A), while the temperature of $24^{\circ} \mathrm{C}$ caused a significant increase in the gene expression of the proliferating cell nuclear antigen ( $p c n a$ ) respect to the other groups (Figure 2B).

In white muscle, $h s p 30$ remained also unaltered, but $h s p 90 b$ gene expression was highest at $28^{\circ} \mathrm{C}$ (Figure 2C). Concerning pcna, a significant up-regulation at $24^{\circ} \mathrm{C}$ compared with the $19^{\circ} \mathrm{C}$ condition as in bone was observed (Figure 2D).

\section{GH-IGFs Axis-, Osteogenic-, and Myogenic-Related Genes Expression in Bone and White Muscle Tissues}

In bone, the mRNA levels of igf-1, igf-2, igfbp-4, igfbp-5b, and igf-1 $\mathrm{ra}$ were significantly down-regulated at $28^{\circ} \mathrm{C}$ compared with the $19^{\circ} \mathrm{C}$ reared fish and, in most cases, compared to the $24^{\circ} \mathrm{C}$ condition as well (Figures 3A,B). Contrarily, $i g f b p-1 a, g h r-1, g h r-$ 2 , and igf-1rb did not show differences among groups, although the former presented a tendency to gradually increase along with temperature. Concerning the osteogenic genes analyzed, none of them showed significant differences in response to temperature treatment under the experimental in vivo conditions tested (Figure 3C).

In white muscle, igf- 1 mRNA levels were lower at $28^{\circ} \mathrm{C}$, although differences were only significant compared to $24^{\circ} \mathrm{C}$ exposed fish (Figure 3D). Moreover, igfbp-1a showed the same pattern as observed in bone tissue, significantly increasing its expression along with temperature. igf-2 and igfbp-4 did not revealed differences among groups, and $i g f b p-5 b$ was not detectable in this tissue. Furthermore, the levels of expression of $g h$ and igf-1 receptors were unaltered for $g h r-1$ compared with the group of $19^{\circ} \mathrm{C}$ but were significantly lower for $g h r-2$ and $i g f-1 \mathrm{rb}$ at $24^{\circ} \mathrm{C}$ and for igf- $1 \mathrm{ra}$ at 24 and $28^{\circ} \mathrm{C}$ (Figure 3E). With regards to the myogenic-related genes, the expression of myod 1 and $m r f 4$ was significantly lower in the $24^{\circ} \mathrm{C}$-held fish compared to the other two groups, while myod 2 and myogenin mRNA levels were significantly higher in the fish kept at $28^{\circ} \mathrm{C}$, and neither muscle growth inhibitor, $m s t n 1$ nor $m s t n 2$, were affected by the rearing temperature (Figure 3F).

In addition, the expression of igfbp-2b was analyzed in both tissues, although none of them showed detectable levels.

\section{Lipid Metabolism-Related Genes Expression in White Muscle Tissue}

The fatty acid transporter $c d 36$ was significantly up-regulated with the temperature rise, showing the fish at $28^{\circ} \mathrm{C}$ the highest mRNA levels. The expression of fatp 1 remained unaltered, but fabp 11 was significantly enhanced at 24 and $28^{\circ} \mathrm{C}$ compared with the $19^{\circ} \mathrm{C}$ group (Figure 4A). Concerning lipases, although hsl mRNA levels were not different among groups, lipa and $l p l-l k$ transcript levels were significantly increased in $28^{\circ} \mathrm{C}$, or 24 and $28^{\circ} \mathrm{C}$-exposed fish, respectively, compared with the $19^{\circ} \mathrm{C}$ group. In parallel to this, significant up-regulation of the lipase maturation factor $(\operatorname{lm} f 1$, an essential gene for the folding and assembly of LPL) was detected in the $28^{\circ} \mathrm{C}$ reared fish (Figure 4B). Regarding $\beta$-oxidation markers, the gene expression of mitochondrial carnitine palmitoyltransferases (cpt1a and cpt1b) was significantly lower in juveniles maintained at 24 and $28^{\circ} \mathrm{C}$ when compared with fish reared at $19^{\circ} \mathrm{C}$, while hydroxyacyl-CoA dehydrogenase hadh expression did not show significant differences among groups. Contrarily, the mitochondrial uncoupling protein $u c p 2$ showed significantly higher mRNA levels with increased temperature (Figure 4C). 
TABLE 1 | Primers used in the qPCR analyses: sequences, melting temperatures (Tm), and GenBank accession numbers.

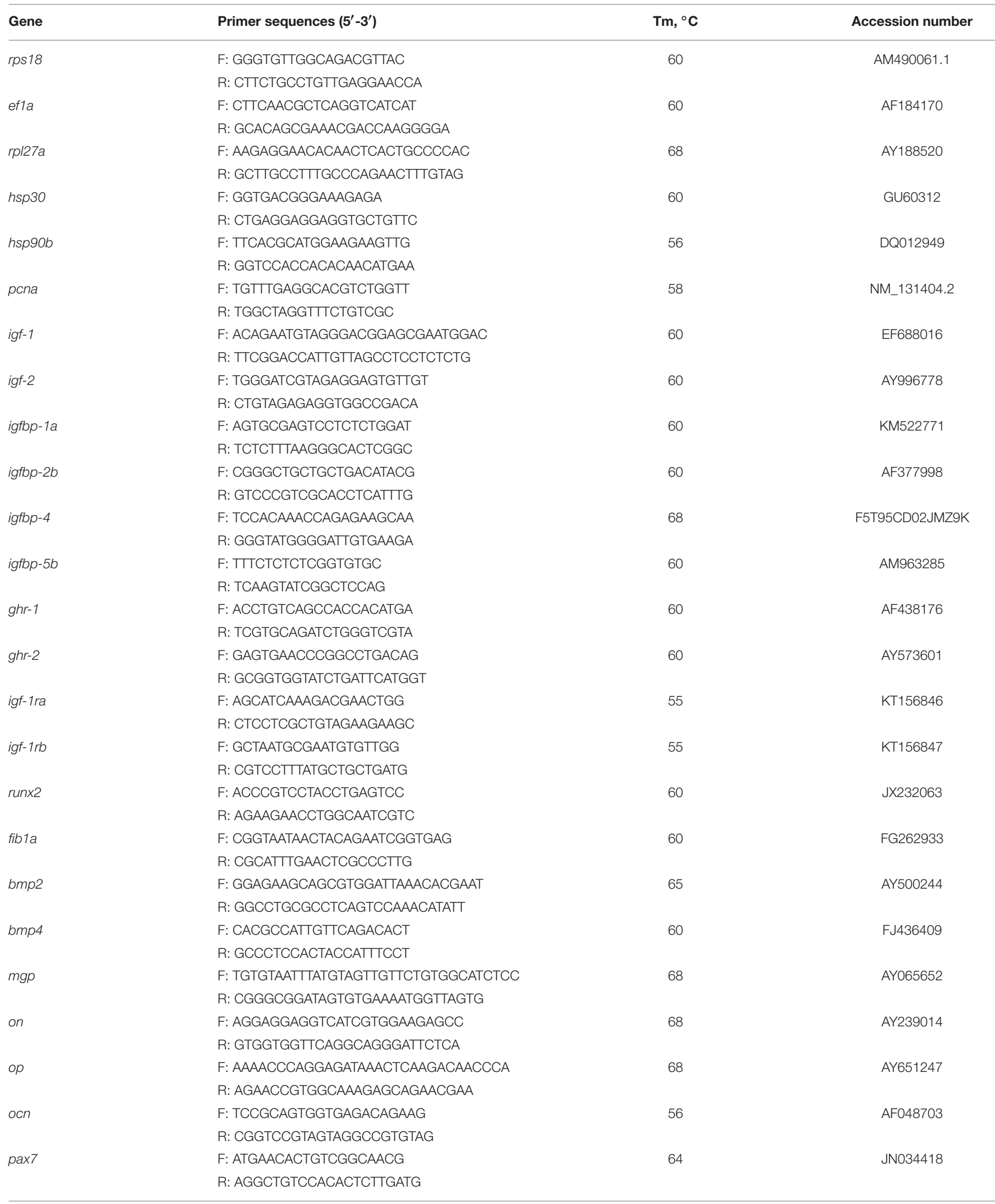


TABLE 1 | Continued

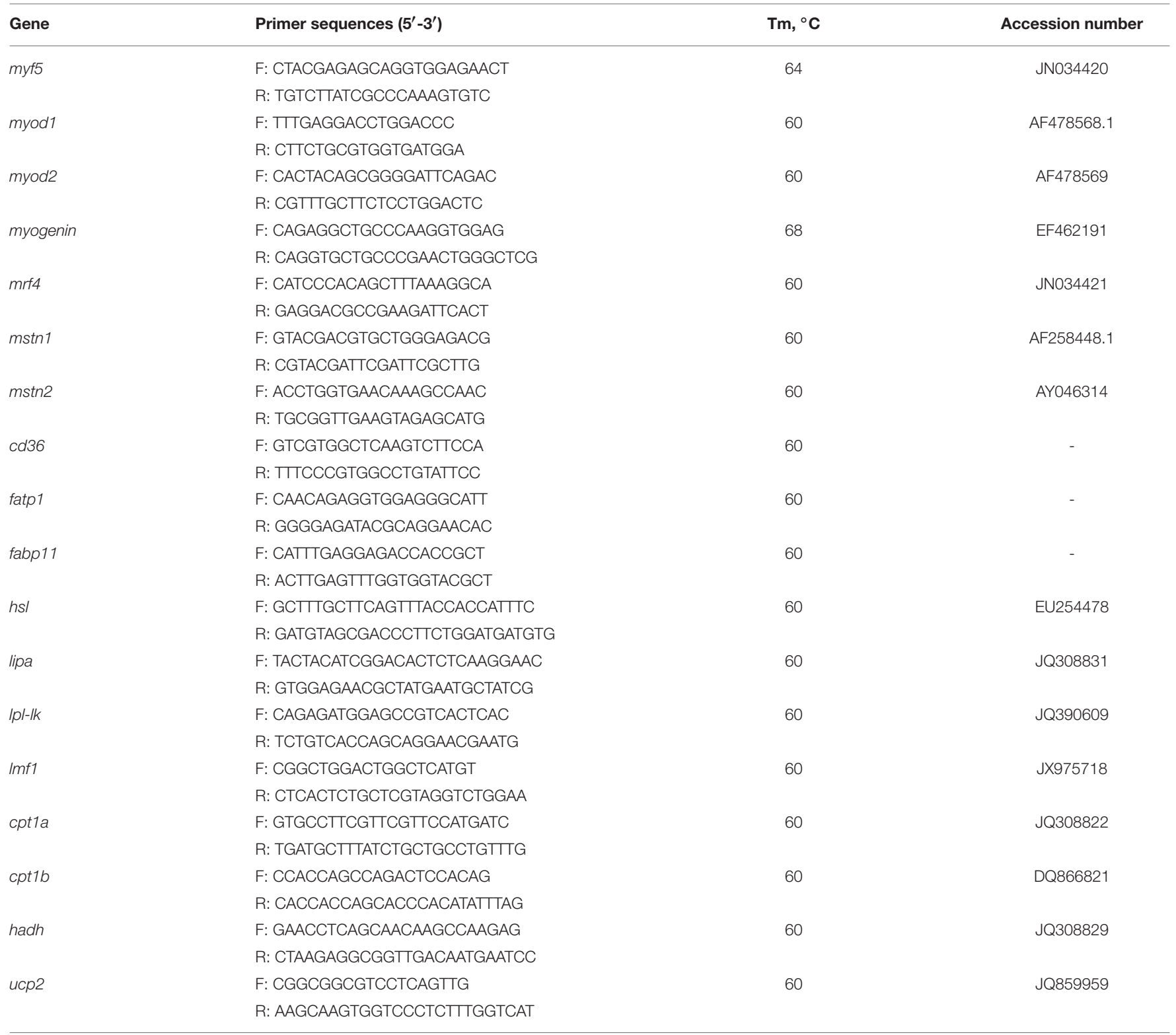

F, forward; $R$, reverse. rps18, ribosomal protein s18; ef1a, elongation factor 1 alpha; rpl27a, ribosomal protein 127a; hsp30, heat shock protein 30; hsp90b, heat shock protein 90b; pcna, proliferating cell nuclear antigen; igf-1, insulin-like growth factor 1; igf-2, insulin-like growth factor 2; igfbp-1a, insulin-like growth factor binding protein 1a; igfbp-2b, insulin-like growth factor binding protein 2b; igfbp-4, insulin-like growth factor binding protein 4; igfbp-5b, insulin-like growth factor binding protein 5b; ghr-1, growth hormone receptor 1; ghr-2, growth hormone receptor 2; igf-1ra, insulin-like growth factor 1 receptor a; igf-1rb, insulin-like growth factor 1 receptor b; runx2, runt-related transcription factor 2; fib 1a, fibronectin subunit 1a; bmp2, bone morphogenetic protein 2; bmp4, bone morphogenetic protein 4; mgp, matrix gla protein; on, osteonectin; op, osteopontin; ocn, osteocalcin; pax7, paired box 7; myf5, myogenic factor 5; myod1, myogenic differentiation 1; myod2, myogenic differentiation 2; myogenin, myogenin; mrf4, myogenic regulatory factor 4; mstn 1, myostatin 1; mstn2, myostatin 2; cd36, cluster of differentiation 36; fatp1, fatty acid transport protein 1; fabp11, fatty acid binding protein 11; hsl, hormone sensitive lipase; lipa, lipase a; Ipl-Ik, lipoprotein lipase-like; Imf1, lipase maturation factor 1; cpt1a, carnitine palmitoyltransferase 1a; cpt1b, carnitine palmitoyltransferase 1b; hadh, hydroxyacil-CoA dehydrogenase; ucp2, uncoupling protein 2.

\section{Characterization of the Bone-Derived Cells Culture}

The effects of temperature during the differentiation of gilthead sea bream bone-derived cells are presented in Figure 5A. Morphologically, in all three groups, the cells showed at day 8 a spindle-like phenotype that changed to a polygonal one at day 15 as the cells differentiated spontaneously into osteoblasts.
Moreover, deposits of minerals started to accumulate in the ECM, although mineral nodules were apparently in greater proportion in cells derived from the $19^{\circ} \mathrm{C}$-reared fish compared to the other two groups. Besides, as shown in Figure 5B, significantly lower viability values were found in cells coming from fish reared at 24 and $28^{\circ} \mathrm{C}$, compared with those at $19^{\circ} \mathrm{C}$; and the same was observed concerning the deposition 

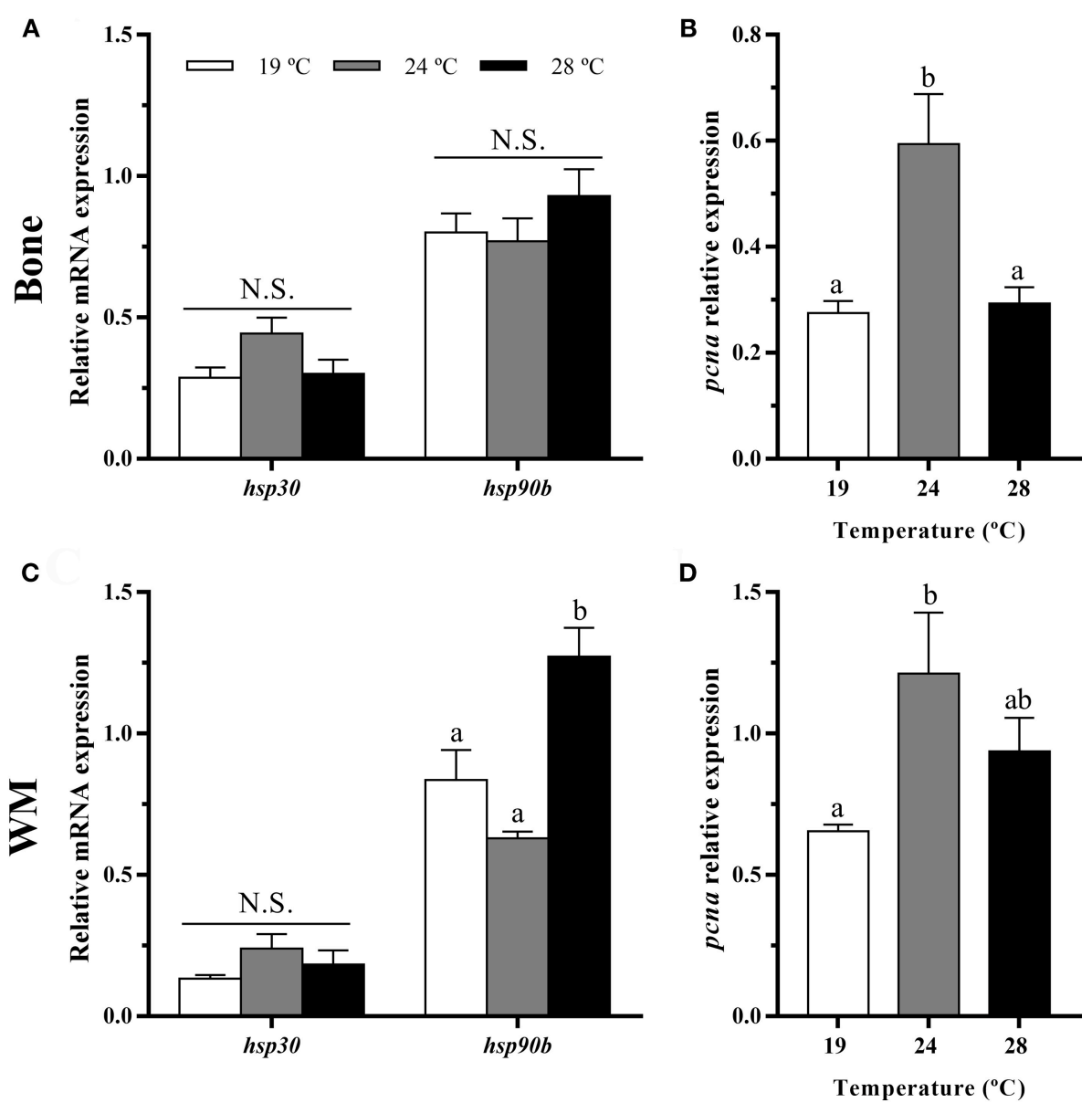

FIGURE 2 | In vivo effects of temperature over the gene expression of heat shock proteins and a proliferation marker in gilthead sea bream in (A,B) bone and (C,D) white muscle (WM). Relative mRNA expression normalized to ef1a and rps18 of (A,C) $h s p 30$ and $h s p 90 b$ and $(\mathbf{B}, \mathbf{D})$ pcna. Data are shown as Mean + SEM $(n=8)$. Significant differences among fish held at different temperatures were determined by one-way ANOVA and are indicated by different letters ( $p<0.05)$. N.S., non-significant.

of minerals in the ECM (Figure 5C), which agreed with the visual observation.

\section{HSPs and Proliferation Marker Genes Expression in Bone-Derived Cells}

Exposure of gilthead sea bream juveniles to $24^{\circ} \mathrm{C}$ of temperature significantly increased the expression of $h s p 30$ and $h s p 90 b$ transcript levels in bone-derived cultured cells compared to those coming from the other fish (Figure 6A). In addition, a significant down-regulation of the proliferation marker pcna gene expression was detected in the $28^{\circ} \mathrm{C}$ cells compared with those obtained from $24^{\circ} \mathrm{C}$-held fish (Figure 6B).

\section{GH-IGFs Axis- and Osteogenic-Related Genes Expression in Bone-Derived Cells}

The analysis of GH-IGFs system-related genes expression in cultured bone-derived cells revealed no differences among groups (Figures 7A,B). Regarding the expression of osteogenic genes, significant differences were neither observed for most of them but significant up-regulation of on, op, and ocn gene expression was found in cells coming from gilthead sea bream maintained at elevated temperatures, compared with those cells from $19^{\circ} \mathrm{C}$-reared fish (Figure 7C). To corroborate the determination of the bone-derived cultured cells toward the osteogenic lineage, the gene expression of pax7, one of the main transcription factors shaping the fate of MSCs into the muscular lineage, was analyzed, resulting undetectable.

\section{DISCUSSION}

As existing literature reports, an increment of water temperature has been proved to be a valid approach to evaluate impact of global climate change on physiological responses in various fish species $(6,15,25,34,35)$. Besides, we have recently described in gilthead sea bream temperature-dependent differential expression of genes involved in osteogenesis, indicating a 

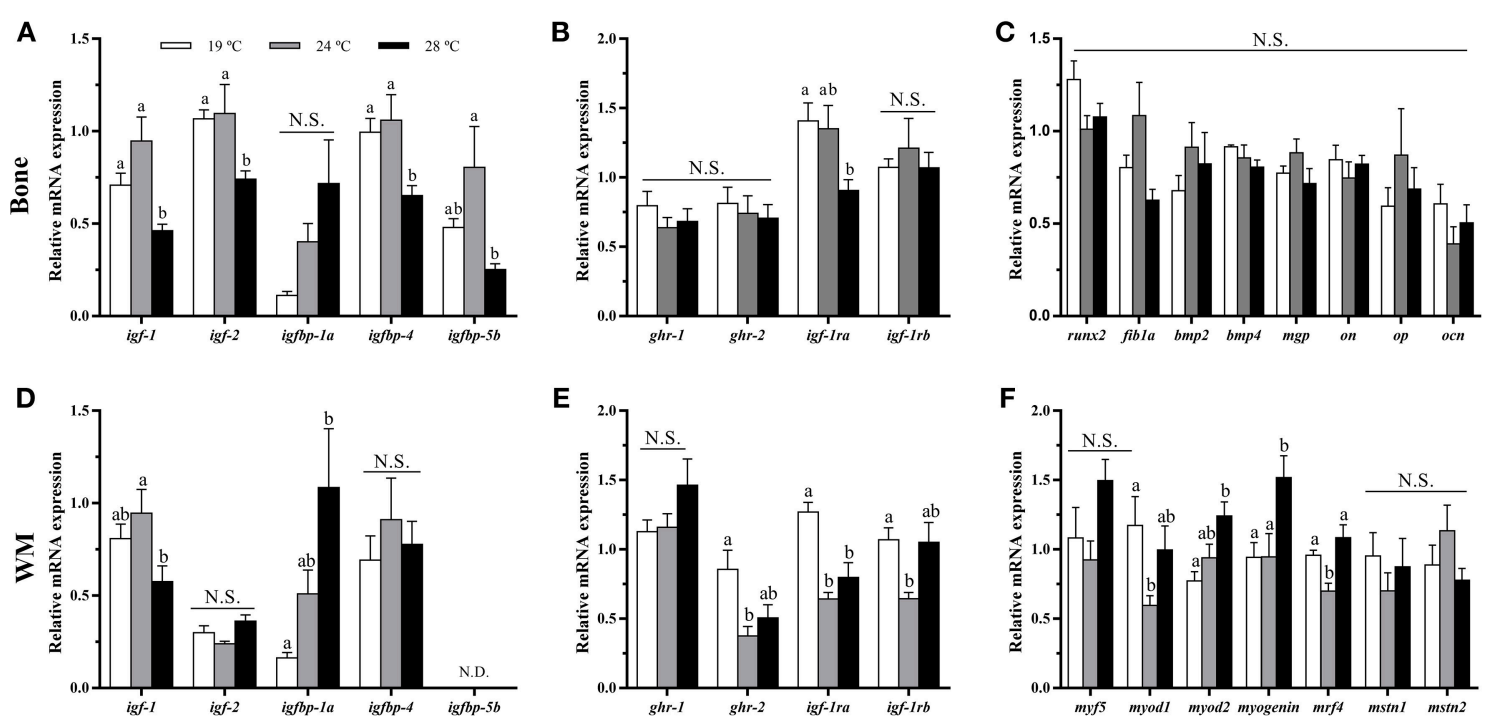

FIGURE 3 | In vivo effects of temperature over the expression of GH-IGFs axis-, osteogenic-, and myogenic-related genes in (A-C) bone and (D-F) white muscle (WM). Relative mRNA expression normalized to ef1a and rps18 of (A,D) igf-1, igf-2, and igf binding proteins (1a, 4, and 5a), (B,E) gh and igf-1 receptors, (C) runx2, fib1a, bmp2, bmp4, mgp, on, op, and ocn, and (F) myf5, myod1, myod2, myogenin, mrf4, mstn1, and mstn2. Data are shown as Mean + SEM ( $n=8$ ). Significant differences among fish held at different temperatures were determined by one-way ANOVA and are indicated by different letters ( $p<0.05)$. N.S., non-significant; N.D., non-detectable.

modulation of bone formation caused by this abiotic factor (20). In the current study, the aim was to characterize the effects of increased temperature in gilthead sea bream juveniles' musculoskeletal growth, muscle lipid metabolism and, in the in vitro development of primary cultured bone-derived cells to test the hypothesis that global climate change modulates the expression of key genes locally in bone and muscle, which might increase the occurrence of skeletal anomalies in this species.

\section{Effects of Temperature on Cell Culture Development}

The bone-derived cultured cells from gilthead sea bream vertebrae gave an initial homogenous population of cells. At the first stages, cells were mostly triangular as previously reported for this species (21) and mammalian bone marrow stem cells (36) and, up to day 8 there were no differences in morphology among the three temperature groups. At day 15, cell differentiation became more evident, with the change into a polygonal shape, characteristic of the osteoblast phenotype (36). These changes followed the profile also reported for gilthead sea bream either in primary cultured cells (21) or the osteoblast-like VSa16 cell line (37). This change in morphology together with the absent levels of pax7 and the elevated expression of osteogenic-genes, confirmed that all three cultures performed in the present study were determined toward the osteogenic lineage. Nevertheless, the increase in temperature appeared to lead toward a disrupted, or at least retarded, osteogenic process, since a decrease in cell viability and mineralization was observed in bone cells derived from 24 to $28^{\circ} \mathrm{C}$-held fish compared with the $19^{\circ} \mathrm{C}$ group. Reduced mineralization caused by a high-temperature treatment was also found by Ytteborg et al. (38) in Atlantic salmon vertebral tissue, supporting this hypothesis.

\section{Effects of Temperature on hsps and pena Gene Expression in vivo and in vitro}

Although the gene expression of $h s p 90 b$ was increased in vivo only in the muscle tissue under the highest temperature tested, the in vitro experiment showed direct evidence of water temperature up-regulating $h s p 30$ and $h s p 90 b$; thus, supporting the stressful condition induced to the animals. A similar response was reported for both genes in the same gilthead sea bream in vitro model when similar temperature changes were applied directly into the cells (20). Previous studies in larvae of sole and grass carp (Ctenopharyngodon idella) also described an increased expression of $h s p 90$ in response to a temperature rise $(39,40)$, as a protective mechanism against thermal stress. In fact, an increase in $h s p 30$ mRNA levels was observed only after $3 \mathrm{~h}$ of an in vivo temperature increase in rainbow trout (Oncorhynchus mykiss) (41). Similar activations of chaperones involved in protein folding have been reported in muscle tissue of gilthead sea bream (42) and rainbow trout (43) facing another stressful situation such as fasting.

The proliferation marker pcna showed the same pattern of expression in vivo in bone and muscle than in vitro in bone-cultured cells, with increased mRNA levels in $24^{\circ} \mathrm{C}$ reared fish respect to the other groups. Thus, despite the cells showed reduced viability with the increase in temperature, this up-regulation of pcna could be considered a compensatory response, attempting these cells to recover from their initial heat stress-related situation. Accordingly, that could be considered a compensatory growth mechanism in vivo. Thus, it appears that $24^{\circ} \mathrm{C}$ would be the limiting temperature to properly 

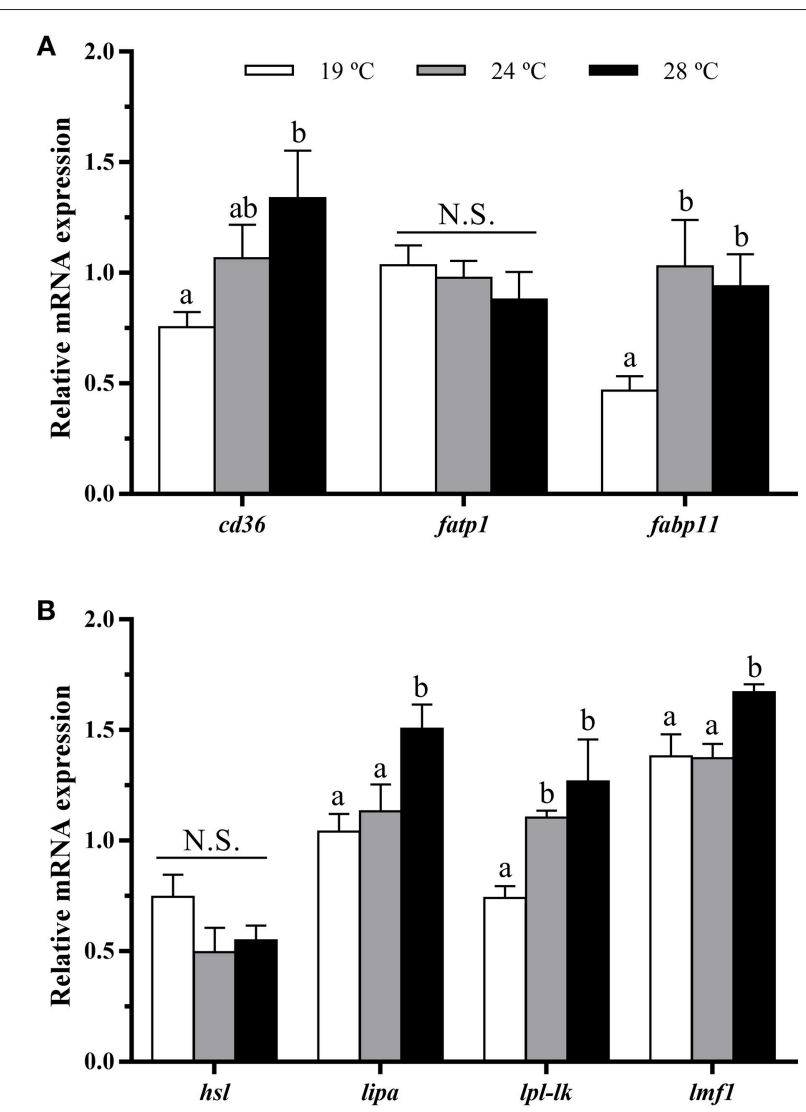

C

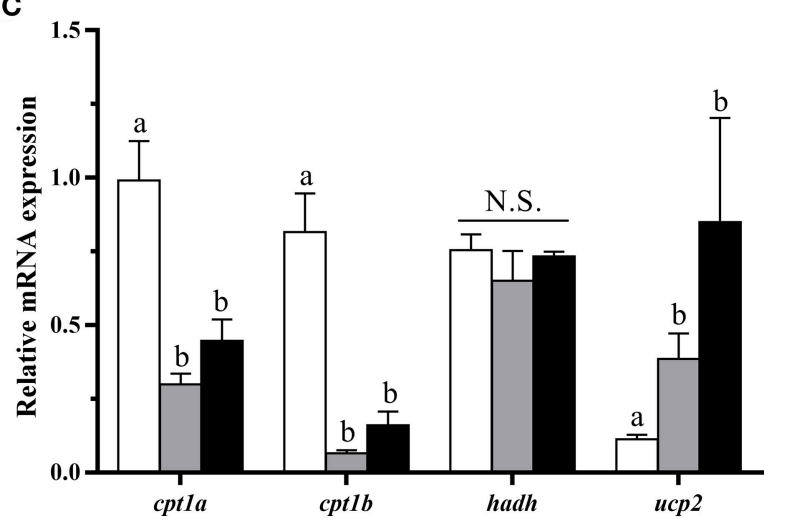

FIGURE 4 | In vivo effects of temperature over the expression of lipid metabolism-related genes in white muscle. Relative mRNA expression normalized to rps18 and rpl27a of (A) fatty acid transporters cd36, fatp1, fabp11, (B) lipases $h s l$, lipa and Ip-lk, Imf1, and (C) $\beta$-oxidation markers cpt1a, $c p t 1 b$, hadh, and ucp2. Data are shown as Mean + SEM $(n=8)$. Significant differences among fish held at different temperatures were determined by one-way ANOVA and are indicated by different letters $(p<0.05)$. N.S., non-significant.

grow gilthead sea bream, being the condition of $28^{\circ} \mathrm{C}$ fairly challenging. This is in agreement with the range of adequate rearing temperatures reported for this species $\left(16-22^{\circ} \mathrm{C}\right)$ not causing significant harmful health effects and/or inducing skeletal malformations (14). Similarly, a previous study carried out in human osteosarcoma cells revealed that an increase in temperature outside optimum has a pronounced inhibitory effect on proliferation rate (44).

\section{Effects of Temperature on GH/IGFs Axis-Related Genes Expression in vivo and in vitro}

The expression of igf- 1 was significantly decreased in both bone and muscle tissues of $28^{\circ} \mathrm{C}$-held fish when compared with fish reared at 24 or $19^{\circ} \mathrm{C}$, while its expression was not detectable in cultured osteoblasts. IGF-1 plays an important role inducing not only muscle differentiation and hypertrophy, but also bone matrix production $(16,45)$. The down-regulating effect of high temperature on igf-1 observed in gilthead sea bream has been also reported in muscle of different fish species (i.e., Atlantic salmon and southern flounder), as well as, in IGF-1 plasma levels $(6,46,47)$, suggesting restricted growth. Notwithstanding, similar studies in rainbow trout showed contrarily, an increase in plasma GH and IGF-1 levels with high temperature $(7,8)$, overall suggesting that the response to temperature increase of the major growth factors in fish could be species-specific. Regarding igf-2, changes were not observed among groups in muscle and cultured bone cells, although the same response as igf- 1 was observed in the bone in vivo, indicating that this tissue appears to be more sensitive to changes in temperature. This data is in agreement with that observed previously in unresponsive rainbow trout muscle, both at mRNA and plasma levels (8); however, in Atlantic salmon, Hevrøy et al. (6) found that igf-2 mRNA levels were significantly down-regulated in muscle and liver after 45 days of exposition to warm temperature but not after only 15 days. Thus, it cannot be excluded that a prolonged trial time could have affected the expression of this gene in the present study as well.

Concerning the $\mathrm{GH}$ and IGF-1 receptors, juveniles held at 24 and $28^{\circ} \mathrm{C}$ presented in muscle significantly lower levels of expression of igf- $1 \mathrm{ra}$ than at $19^{\circ} \mathrm{C}$; those reared at $24^{\circ} \mathrm{C}$ also had decreased igf-1rb and $g h r-2$, and in bone those at $28^{\circ} \mathrm{C}$ also showed reduced igf-1ra mRNA levels. Wargelius et al. (16) revealed that an increase in the gene expression of igf1ra relates with an increase in bone density in Atlantic salmon. Thus, the decrease in igf-1ra expression observed in gilthead sea bream could lead to reduced mineralization in the longterm caused by the high rearing temperature, which would be in agreement with that observed by Ytteborg et al. (48) in the former species. Therefore, in this context, the results of the present study suggest that the GH/IGFs axis is influenced in gilthead sea bream by elevated temperature to locally decrease the expression of $g h r s$, igfs, and igf-1rs in bone and muscle in order to delay musculoskeletal growth. Interestingly, although differences exist between the in vivo and in vitro data, which could be due to modulation of the gene expression by systemic factors in the whole animal, the results obtained in the bone-derived cultured cells reflect this impaired situation as well.

With regards to the IGFBPs of major local action in the musculoskeletal tissues, the same increasing pattern in expression with temperature was observed concerning igfbp-1a in white 

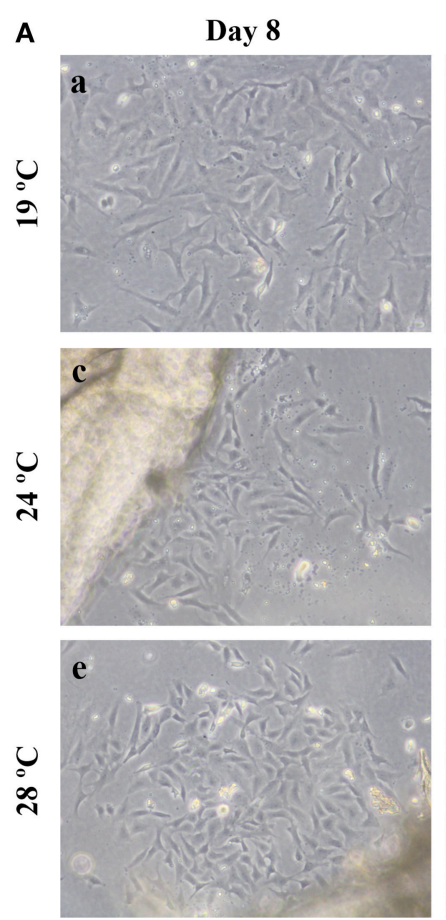

Day 15
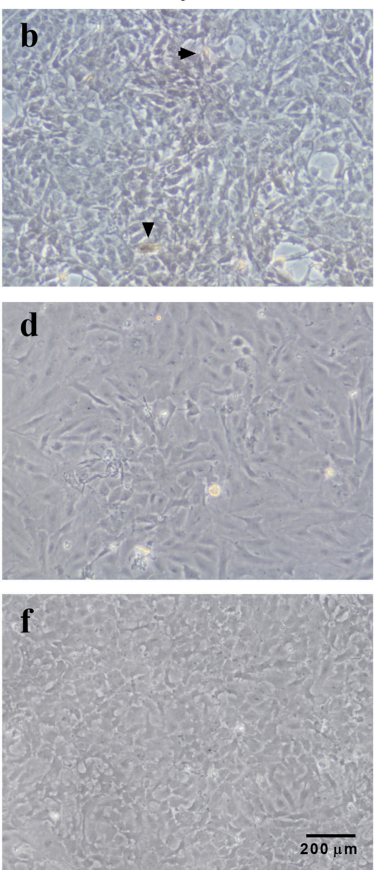

B

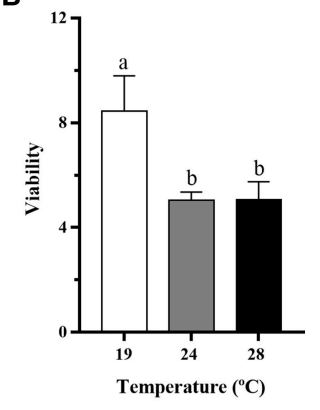

C

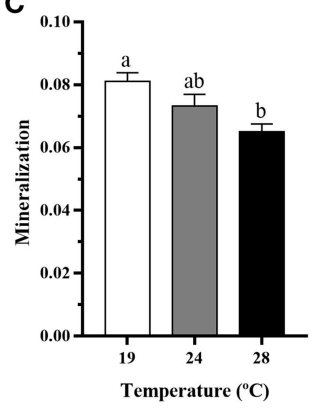

FIGURE 5 | (A) Representative images of cells derived from vertebrae bone of gilthead sea bream reared at different temperatures, at (a,c,e) day 8 and (b,d,f) day 15 of culture development. Magnification, 10x. Arrowheads indicate the presence of mineral nodules. (B) Quantification of viability in gilthead sea bream cultured bone-derived cells using an MTT assay presented as fold change of day 15 relative to day 8 of culture. (C) Quantification of mineralization in gilthead sea bream cultured bone-derived cells at day 20 determined by ARS staining. Data are shown as Mean + SEM $(n=10)$. Different letters among temperature groups indicate significant differences, calculated by one-way ANOVA $(p<0.05)$.
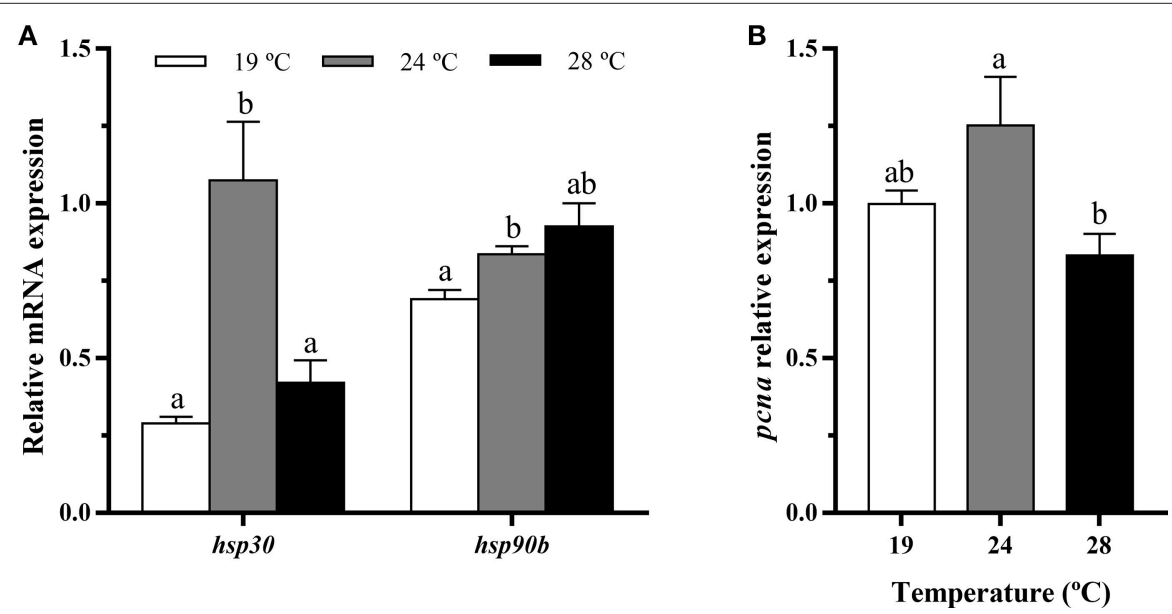

FIGURE 6 | In vitro effects of fish rearing temperature over the gene expression of heat shock proteins and a proliferation marker in bone-derived cells at day 15 of culture development. Relative mRNA expression normalized to ef1a and rps18 of (A) $h s p 30$ and $h s p 90$ and (B) pcna. Data are shown as Mean + SEM ( $n=6-7)$. Significant differences among temperatures groups gene were determined by one-way ANOVA and are indicated by different letters ( $p<0.05)$.

muscle and bone, as previously found in Atlantic salmon muscle (6). Previous studies in zebrafish (Danio rerio) revealed that elevated expression of igfbp-1a limits cellular actions of IGF1 , being an important growth and developmental inhibitor (49). Moreover, this binding protein has been associated with stressful or negative conditions, since a strong relation with elevated serum cortisol levels has been reported $(50,51)$. In this context, the gradual increase of igfbp-1a along with temperature observed in this study, suggests impaired growth conditions in agreement with the reduced expression of igfs observed at 

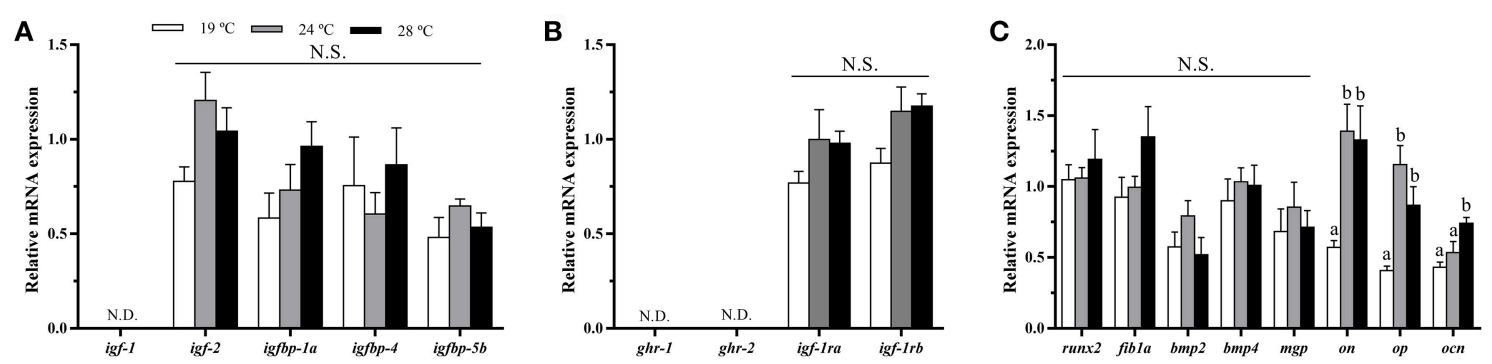

FIGURE 7 | In vitro effects of fish rearing temperature over the expression of GH-IGFs axis- and osteogenic-related genes in bone-derived cells at day 15 of culture development. Relative mRNA expression normalized to ef1a and rps18 of (A) igf-1, igf-2 and igf binding proteins (1a, 4, and 5a), (B) gh and igf-1 receptors and (C) runx2, fib1a, bmp2, bmp4, mgp, on, op, and ocn. Data are shown as Mean + SEM ( $n=6-7)$. Significant differences among temperatures groups were determined by one-way ANOVA and are indicated by different letters ( $p<0.05)$. N.S., non-significant; N.D., non-detectable.

$28^{\circ} \mathrm{C}$. Furthermore, igfbp- 4 and igfbp-5b mRNA levels were also significantly decreased in bone tissue of $28^{\circ} \mathrm{C}$-held fish, although remained unaltered in muscle and bone cells. In previous studies, these binding proteins have been reported as positive regulators of IGF-1 actions, with igfbp-5b promoting bone differentiation (45); and its mRNA levels being highly correlated with igf-1 and igf-2 in muscle (10, 32, 52, 53). Therefore, altogether, the downregulation of $i g f b p-4$ and $i g f b p-5 b$ in bone tissue and the increase of $i g f b p-1 a$ in muscle of gilthead sea bream maintained at $28^{\circ} \mathrm{C}$, indicates that such high temperature is an unfavorable condition, leading to reduced musculoskeletal growth and differentiation in this species.

\section{Effects of Temperature on Osteogenic- and Myogenic-Related Genes Expression in vivo and in vitro}

In the present study, although none of the osteogenic-related genes analyzed showed differences in vivo, increasing water temperature was sufficient to induce an up-regulating response on some genes involved in the mineralization of the ECM (on, op, and $o c n$ ) in the cultured bone-derived cells, suggesting that the thermal history can influence the developmental plasticity of the osteogenic process in vitro. Interestingly, the ECM glycoprotein ON has been reported as a heat shock protein having chaperone-like properties to prevent collagen denaturation $(54,55)$. Therefore, as it was observed in rainbow trout by Currie et al. (41) and in a previous study by our group using the same cellular system (20), the increase in on expression caused by changes in temperature could potentially represent an initial response of bone cells to stressful conditions. According to this, the increase in on mRNA levels may also suggest a negative effect for ECM production and mineralization, which agrees with the reduced number of deposited minerals in the ECM along with temperature in the bone-cultured cells of the present study. Moreover, the elevated expression of $o p$, a well-known inhibitor of matrix mineral deposition (56) supports this improper mineralization of the bone when fish are maintained at high temperatures. However, the ability of OP to regulate this process depends on its state of phosphorylation (57), thus, further analyses should be done to confirm this hypothesis.
Concerning in vivo studies, after a long-term hightemperature treatment in Atlantic salmon, Ytteborg et al. (38) reported that the mRNA levels of runx2 (the key transcription factor of osteogenesis), decreased when fish reached $15 \mathrm{~g}$ but not at $2 \mathrm{~g}$ of body weight; whereas other non-collagenic ECM molecules such as ocn, on, or colla1 were down-regulated already at the $2 \mathrm{~g}$ stage. These authors proposed that these results might suggest a defect in the late maturation of osteoblasts, which agrees with the lower mineral density and shorter lengthheight proportion observed in the vertebrae of these animals (38). It also agrees with the subsequent significantly increased incidence of malformations found in the fish reared at high temperature at body weights of 15 and $60 \mathrm{~g}$. Moreover, the same authors observed, in an in vitro study with precursor muscle cells differentiated into osteoblasts and cultured at an elevated temperature, a reduced expression of ocn and collal (48). In gilthead sea bream, expression of osteogenic genes was modified by temperature in both embryo and larval stages, but in the juveniles, differences were only observed after producing a temperature challenge (20). In the same study, lower transcript levels of most of the osteogenic genes analyzed in cultured osteoblasts in response to a long-term treatment of increased temperature were reported. Overall, these data suggest that at a transcriptional level, the deleterious effects of temperature on bone development could depend on the time of exposure. Therefore, it cannot be discarded that a prolonged temperature treatment could have also affected the expression of osteogenic genes in gilthead sea bream in vivo, pointing out then that osteoblast differentiation and bone ECM mineralization could be impaired.

The coordinated expression of MRFs to properly control muscle development can be modulated by temperature in teleost fish, thus affecting muscle growth $(42,58)$. In the present study, myod1 transcript levels were reduced in the fish maintained at $24^{\circ} \mathrm{C}$, while myogenin and $m r f 4$ expression was highest in the $28^{\circ} \mathrm{C}$-reared fish, suggesting potentially slackened cell proliferation but enhanced myocyte differentiation with the increase in water temperature, overall uncoupling the myogenic process. In this framework, with high rearing temperatures, gilthead sea bream musculoskeletal growth would not be under harmonic conditions, which could be leading in the long-term to increased prevalence of bone deformities. 


\section{Effects of Temperature on Muscle Lipid Metabolism-Related Genes Expression in vivo}

The increase of temperature, up-regulated in the present work the muscle expression of the fatty acid transporter and binding protein $c d 36$ and fabp 11, respectively, suggesting elevated fatty acid uptake and intracellular transport, upon high-temperature conditions. These data are in accordance with a recent study by Zoladz et al. (59), which reported enhanced protein expression of CD36 in rat skeletal muscle under hyperthermia. Nevertheless, the function of FABP11, which is probably an isoform restricted to fishes, is not completely known (60). With regards to the endothelial enzymes with a triglycerides lipase activity, gilthead sea bream juveniles held at $28^{\circ} \mathrm{C}$ presented significantly higher mRNA levels of lipa and $l p l-l k$, an exclusive fish lineage isoform of LPL (59). Regulation of the latter enzyme is far from being established yet, although it is known that in skeletal muscle of gilthead sea bream, changes in LPL-like are correlated with LMF1 (61), an endoplasmic reticulum membrane protein involved in the post-translational folding and assembly of LPL, among other proteins (62). This agrees with the results of this study, where $\operatorname{lmf} 1 \mathrm{mRNA}$ levels were also increased as temperature was raised. Contrarily, the increase of temperature did not induce significant changes in $h s l$ gene expression among groups, suggesting that fatty acids are mostly being uptaken by the muscle from circulating triglycerides, or non-esterified fatty acids provided by adipose tissue. Recent studies in Atlantic salmon and catfish (Pelteobagrus vachellii) demonstrated a reduction in hepatic triglycerides and relative viscera weight during exposure to elevated temperatures $(6,63)$, which illustrated that lipid metabolism may have increased, accelerating utilization of lipids as an energy source in peripheral tissues. In accordance with this, in rainbow trout exposed to high temperatures, endogenous lipid stores remained the most important energy source contributing up to $55 \%$ of total demand (64).

Concerning $\beta$-oxidation, an association between water temperature and fatty acid catabolism has been shown, but with inconsistent results in the literature. A recent study in Atlantic salmon showed an increase of $\beta$-oxidation in white muscle with increased temperature (25), while changes were not observed by Hevrøy et al. (47), and another study in rainbow trout reported increased capacities for oxidizing lipids at cold temperatures (65). In any case, it has been generally accepted that liver and red muscle, but not white muscle, are the most important tissues involved in fatty acid catabolism in fish; thus, an increase in water temperature has been shown to induce increased $\beta$-oxidation primarily in those tissues $(66,67)$. Other study in salmon found that elevation of water temperature was responsible for reduced $\beta$-oxidation in liver (47). These last data would be in agreement with the present study, where cpt1a and $c p t 1 b$ were down-regulated at 24 and $28^{\circ} \mathrm{C}$ compared with the low-temperature group, considering the flux of $\beta$-oxidation is primarily determined by CPT1, which allows long chain fatty acids to enter into the mitochondria (25).

Notwithstanding, temperature can also affect mitochondrial uncoupling. The increase of temperature from 19 to $28^{\circ} \mathrm{C}$ led in gilthead sea bream muscle to the up-regulation of the uncoupling protein $u c p 2$, indicating a higher proton leak, which is in agreement with previous studies in skeletal muscle in mammals $(68,69)$. UCPs are known to be activated not only by free fatty acids, but also by reactive oxygen species $(70,71)$. According to this, $u c p 2$ may play a role as a mechanism for attenuating the possible increase in reactive oxygen species associated with elevated temperature; therefore, overall indicating a less efficient use of fatty acids to obtain energy in this species, upon these environmental conditions.

\section{CONCLUSIONS}

To sum up, the present work reports that an increase in water rearing temperature from 19 to 24 and specially $28^{\circ} \mathrm{C}$ causes in gilthead sea bream juveniles unfavorable growth conditions for the musculoskeletal system due to reduced gene expression of members of the GH/IGFs system and specific MRFs. In white muscle as well, as energetic demand is increased along with temperature, the uptake of fatty acids is enhanced, although apparently, their use as an energy source is less efficient. In addition, the high temperatures applied in vivo, induced changes in vitro in the expression of several key osteogenic genes, suggesting reduced osteoblasts development and matrix production, consistent with the decrease observed in the deposition of minerals. Overall, the present study provides new insights into the possible impact of global climate change in this important Mediterranean species, demonstrating that temperature is a key environmental factor whose increase can lead to unbalanced muscle and bone growth, which should be considered to take preventive measures to reduce production losses and guarantee the sustainability and success of aquaculture.

\section{AUTHOR CONTRIBUTIONS}

MR-C and EC conceived and designed the experiments. SB-P, $\mathrm{NR}-\mathrm{H}$, and EV performed the experiments. JG, IN, MR-C, and EC contributed reagents and analysis tools. SB-P, NR-H, EV, JG, IN, MR-C, and EC drafted and critically reviewed the paper.

\section{FUNDING}

NR-H and EV are supported by predoctoral fellowships from the Spanish Ministerio de Economía, Industria y Competitividad (MINECO) BES-2015-074654 and BES2013-062949, respectively. This study was supported by funds from the MINECO (projects AGL2014-57974-R to EC and IN and AGL2015-70679-R to JG) and the Generalitat de Catalunya (2017SGR-1574 and Xarxa de Refèrencia d'R+D+I en Aqüicultura).

\section{ACKNOWLEDGMENTS}

The authors would like to thank the personnel from the animal facilities of the Faculty of Biology for the maintenance of the fish. 


\section{REFERENCES}

1. United Nations. Department of Economic and Social Affairs, Population Division. World Population Prospects: The 2015 Revision (2016).

2. Godfray HCJ, Beddington JR, Cute IR, Haddad L, Lawrence D, Muir JF, et al. Food security: the challenge of feeding 9 billion people. Science. (2010) 327:812-9. doi: 10.1126/science.1185383

3. FAO. The State of World Fisheries and Aquaculture - (SOFIA) (2018).

4. IPCC. Climate Change 2014: Synthesis Report. Contribution of Working Groups I, II and III to the Fifth Assessment Report of the Intergovernmental Panel on Climate Change. Pachauri RK, Meyer LA. editors. Geneva: Core Writing Team (2014).

5. Chatakun $\mathrm{P}$, Núñez-Toldrà R, Díaz López EJ, Gil-Recio C, Martínez-Sarrà E, Hernández-Alfaro $\mathrm{F}$, et al. The effect of five proteins on stem cells used for osteoblast differentiation and proliferation: a current review of the literature. Cell Mol Life Sci. (2014) 71:113-42. doi: 10.1007/s00018-0131326-0

6. Hevrøy EM, Hunskår C, de Gelder S, Shimizu M, Waagbø R, Breck O, et al. GH - IGF system regulation of attenuated muscle growth and lipolysis in Atlantic salmon reared at elevated sea temperatures. J Comp Physiol B. (2013) 183:243-59. doi: 10.1007/s00360-012-0704-5

7. Gabillard JC, Weil C, Rescan PY, Navarro I, Gutiérrez J, Le Bail PY. Environmental temperature increases plasma GH levels independently of nutritional status in rainbow trout (Oncorhynchus mykiss). Gen Comp Endocrinol. (2003) 133:17-26. doi: 10.1016/S0016-6480(03) 00156-4

8. Gabillard JC, Weil C, Rescan PY, Navarro I, Gutiérrez J, Le Bail PY. Effects of environmental temperature on IGF1, IGF2, and IGF type I receptor expression in rainbow trout (Oncorhynchus mykiss). Gen Comp Endocrinol. (2003) 133:233-42. doi: 10.1016/S0016-6480(03) 00167-9

9. Reindl KM, Sheridan MA. Peripheral regulation of the growth hormoneinsulin-like growth factor system in fish and other vertebrates. Comp Biochem Physiol Part A Mol Integr Physiol. (2012) 163:231-45. doi: 10.1016/j.cbpa.2012.08.003

10. Fuentes EN, Valdés JA, Molina A, Björnsson BT. Regulation of skeletal muscle growth in fish by the growth hormone - Insulin-like growth factor system. Gen Comp Endocrinol. (2013) 192:136-48. doi: 10.1016/j.ygcen.2013. 06.009

11. García de la serrana D, Macqueen DJ. Insulin-like growth factorbinding proteins of teleost fishes. Front Endocrinol. (2018) 9:80. doi: $10.3389 /$ fendo. 2018.00080

12. Boglione C, Gisbert E, Gavaia P, Witten PE, Moren M, Fontagné S, et al. Skeletal anomalies in reared European fish larvae and juveniles. Part 2: main typologies, occurrences and causative factors. Rev Aquac. (2013) 5:121-67. doi: 10.1111/raq.12016

13. Ytteborg E, Torgersen J, Baeverfjord G, Takle H. The Atlantic salmon (Salmo salar) vertebra and cellular pathways to vertebral deformities. In: Carvalho E, editor. Health and Environment in Aquaculture. Rijeka: InTech (2012). p. 329-58. doi: 10.5772/30750

14. Georgakopoulou E, Katharios P, Divanach P, Koumoundouros G. Effect of temperature on the development of skeletal deformities in gilthead seabream (Sparus aurata Linnaeus, 1758). Aquaculture. (2010) 308:13-9. doi: 10.1016/j.aquaculture.2010.08.006

15. Dionísio G, Campos C, Valente LMP, Conceição LEC, Cancela ML, Gavaia PJ. Effect of egg incubation temperature on the occurrence of skeletal deformities in Solea senegalensis. J Appl Ichthyol. (2012) 28:471-6. doi: 10.1111/j.1439-0426.2012.01996.x

16. Wargelius A, Fjelldal PG, Hansen T. Heat shock during early somitogenesis induces caudal vertebral column defects in Atlantic salmon (Salmo salar). Dev Genes Evol. (2005) 215:350-7. doi: 10.1007/s00427-0050482-0

17. Koumoundouros G, Divanach P, Anezaki L, Kentouri M. Temperature-induced ontogenetic plasticity in sea bass (Dicentrarchus labrax). Mar Biol. (2001) 139:817-30. doi: 10.1007/s0022701 00635
18. Yúfera M, Conceição LEC, Battaglene S, Fushimi H, Kotani T. Early development and metabolism. In: Pavlidis MA, Mylonas CC, editors. Sparidae: Biology and Aquaculture of Gilthead Sea Bream and Other Species. Oxford: Wiley-Blackwell (2011). p. 133-68.

19. Mateus AP, Costa R, Gisbert E, Pinto PIS, Andree KB, Estévez A, et al. Thermal imprinting modifies bone homeostasis in cold-challenged sea bream (Sparus aurata). J Exp Biol. (2017) 220:3442-54. doi: 10.1242/jeb. 156174

20. Riera-Heredia N, Martins R, Mateus AP, Costa RA, Gisbert E, Navarro I, et al. Temperature responsiveness of gilthead sea bream bone; an in vitro and in vivo approach. Sci Rep. (2018) 8:1-14. doi: 10.1038/s41598-018-2 9570-9

21. Capilla E, Teles-García A, Acerete L, Navarro I, Gutiérrez J. Insulin and IGF-I effects on the proliferation of an osteoblast primary culture from sea bream (Sparus aurata). Gen Comp Endocrinol. (2011) 172:107-14. doi: 10.1016/j.ygcen.2011.03.020

22. Salmerón C, Riera-Heredia N, Gutiérrez J, Navarro I, Capilla E. Adipogenic gene expression in gilthead sea bream mesenchymal stem cells from different origin. Front Endocrinol. (2016) 7:113. doi: 10.3389/fendo.2016. 00113

23. Vélez EJ, Lutfi E, Azizi Sh, Perelló M, Salmerón C, RieraCodina $\mathrm{M}$, et al. Understanding fish muscle growth regulation to optimize aquaculture production. Aquaculture. (2017) 467:28-40. doi: 10.1016/j.aquaculture.2016.07.004

24. García de la serrana D, Codina M, Capilla E, Jiménez-Amilburu V, Navarro I, Du SJ, et al. Characterisation and expression of myogenesis regulatory factors during in vitro myoblast development and in vivo fasting in the gilthead sea bream (Sparus aurata). Comp Biochem Physiol Part A Mol Integr Physiol. (2014) 167:90-9. doi: 10.1016/j.cbpa.2013. 10.020

25. Norambuena F, Morais S, Emery JA, Turchini GM. Arachidonic acid and eicosapentaenoic acid metabolism in juvenile Atlantic salmon as affected by water temperature. PLoS ONE. (2015) 10:e0143622. doi: 10.1371/journal.pone. 0143622

26. Sánchez-Gurmaches J, Østbye TK, Navarro I, Torgersen J, Hevrøy EM, Ruyter $\mathrm{B}$, et al. In vivo and in vitro insulin and fasting control of the transmembrane fatty acid transport proteins in Atlantic salmon (Salmo salar). Am J Physiol Integr Comp Physiol. (2011) 301:947-57. doi: 10.1152/ajpregu.002 89.2011

27. Sánchez-Gurmaches J, Cruz-Garcia L, Gutiérrez J, Navarro I. mRNA expression of fatty acid transporters in rainbow trout: in vivo and in vitro regulation by insulin, fasting and inflammation and infection mediators. Comp Biochem Physiol Part A Mol Integr Physiol. (2012) 163:177-88. doi: 10.1016/j.cbpa.2012.06.010

28. Rutkowski JM, Stern JH, Scherer PE. The cell biology of fat expansion. J Cell Biol. (2015) 208:501-12. doi: 10.1083/jcb.2014 09063

29. Montserrat N, Sánchez-Gurmaches J, García de la serrana D, Navarro M, Gutiérrez J. IGF-I binding and receptor signal transduction in primary cell culture of muscle cells of gilthead sea bream: changes throughout in vitro development. Cell Tissue Res. (2007) 330:503-13. doi: 10.1007/s00441-007-0507-2

30. Fotakis G, Timbrell JA. In vitro cytotoxicity assays: comparison of $\mathrm{LDH}$, neutral red, MTT and protein assay in hepatoma cell lines following exposure to cadmium chloride. Toxicol Lett. (2006) 160:171-7. doi: 10.1016/j.toxlet.2005.07.001

31. Salmerón C, García de la serrana D, Jiménez-Amilburu V, Fontanillas R, Navarro I, Johnston IA, et al. Characterisation and expression of calpain family members in relation to nutritional status, diet composition and flesh texture in gilthead sea bream (Sparus aurata). PLoS ONE. (2013) 8:e75349. doi: 10.1371/journal.pone.0075349

32. Vélez EJ, Azizi Sh, Millán-Cubillo A, Fernández-Borràs J, Blasco J, Chan SJ, et al. Effects of sustained exercise on GH-IGFs axis in gilthead sea bream (Sparus aurata). Am J Physiol Regul Integr Comp Physiol. (2016) 310:313-22. doi: 10.1152/ajpregu.00230.2015

33. Pfaffl MW. A new mathematical model for relative quantification in real-time RT - PCR. Nucleic Acids Res. (2001) 29:16-21. doi: 10.1093/nar/29.9.e45 
34. Chatterjee N, Pal AK, Manush SM, Das T, Mukherjee SC. Thermal tolerance and oxygen consumption of Labeo rohita and Cyprinus carpio early fingerlings acclimated to three different temperatures. J Therm Biol. (2004) 29:265-70. doi: 10.1016/j.jtherbio.2004.05.001

35. Mellery J, Geay F, Tocher DR, Kestemont P, Debier C, Rollin X, et al. Temperature increase negatively affects the fatty acid bioconversion capacity of rainbow trout (Oncorhynchus mykiss) fed a linseed oilbased diet. PLoS ONE. (2016) 11:e0164478. doi: 10.1371/journal.pone.0 164478

36. Pittenger MF, Mackay AM, Beck SC, Jaiswal RK, Douglas R, Mosca JD, et al. Multilineage potential of adult human mesenchymal stem cells. Science. (2014) 284:143-8. doi: 10.1126/science.284.54 11.143

37. Pombinho AR, Laizé V, Molha DM, Marques SMP, Cancela ML. Development of two bone-derived cell lines from the marine teleost Sparus aurata; evidence for extracellular matrix mineralization and cell-type-specific expression of matrix Gla protein and osteocalcin. Cell Tissue Res. (2004) 315:393-406. doi: 10.1007/s00441-003-0830-1

38. Ytteborg E, Baeverfjord G, Torgersen J, Hjelde K, Takle H. Molecular pathology of vertebral deformities in hyperthermic Atlantic salmon (Salmo salar). BMC Physiol. (2010) 10:12. doi: 10.1186/1472-6793-10-12

39. Manchado M, Salas-Leiton E, Infante C, Ponce M, Asensio E, Crespo A, et al. Molecular characterization, gene expression and transcriptional regulation of cytosolic HSP90 genes in the flatfish Senegalese sole (Solea senegalensis Kaup). Gene. (2008) 416:77-84. doi: 10.1016/j.gene.2008. 03.007

40. Wu CX, Zhao FY, Zhang Y, Zhu YJ, Ma MS, Mao HL, et al. Overexpression of Hsp90 from grass carp (Ctenopharyngodon idella) increases thermal protection against heat stress. Fish Shellfish Immunol. (2012) 33:42-7. doi: 10.1016/j.fsi.2012.03.033

41. Currie S, Moyes CD, Tufts BL. The effects of heat shock and acclimation temperature on hsp70 and hsp30 mRNA expression in rainbow trout: in vivo and in vitro comparisons. J Fish Biol. (2000) 56:398-408. doi: 10.1111/j.1095-8649.2000.tb02114.x

42. Garcia de la serrana D, Vieira VLA, Andree KB, Darias M, Estévez A, Gisbert E, et al. Development temperature has persistent effects on muscle growth responses in gilthead sea bream. PLoS ONE. (2012) 7:e51884. doi: 10.1371/journal.pone.0051884

43. Rescan PY, Montfort J, Rallière C, Le Cam A, Esquerré D, Hugot K. Dynamic gene expression in fish muscle during recovery growth induced by a fasting-refeeding schedule. BMC Genomics. (2007) 8:1-18. doi: 10.1186/1471-2164-8-438

44. Trieb K, Blahovec H, Kubista B. Effects of hyperthermia on heat shock protein expression, alkaline phosphatase activity and proliferation in human osteosarcoma cells. Cell Biochem Funct. (2007) 25:669-72. doi: $10.1002 /$ cbf.1371

45. Kiepe D, Ciarmatori S, Haarmann A, Tönshoff B. Differential expression of IGF system components in proliferating vs. differentiating growth plate chondrocytes: the functional role of IGFBP-5. Am J Physiol Endocrinol Metab. (2006) 290:363-71. doi: 10.1152/ajpendo.0036 3.2005

46. Luckenbach JA, Murashige R, Daniels HV, Godwin J, Borski RJ. Temperature affects insulin-like growth factor I and growth of juvenile southern flounder, Paralichthys lethostigma. Comp Biochem Physiol A. (2007) 146:95-104. doi: 10.1016/j.cbpa.2006.09.024

47. Hevrøy EM, Waagbø R, Torstensen BE, Takle H, Stubhaug I, Jørgensen $\mathrm{SM}$, et al. Ghrelin is involved in voluntary anorexia in Atlantic salmon raised at elevated sea temperatures. Gen Comp Endocrinol. (2012) 175:118-34. doi: 10.1016/j.ygcen.2011.10.007

48. Ytteborg E, Vegusdal A, Witten PE, Berge GM, Takle H, Østbye TK, et al. Atlantic salmon (Salmo salar) muscle precursor cells differentiate into osteoblasts in vitro: polyunsaturated fatty acids and hyperthermia influence gene expression and differentiation. Biochim Biophys Acta Mol Cell Biol Lipids. (2010) 1801:127-37. doi: 10.1016/j.bbalip.2009.10.001

49. Duan C, Ren H, Gao S. Insulin-like growth factors (IGFs), IGF receptors, and IGF-binding proteins: roles in skeletal muscle growth and differentiation. Gen Comp Endocrinol. (2010) 167:344-51. doi: 10.1016/j.ygcen.2010. 04.009
50. Kelley KM, Haigwood JT, Perez M, Galima MM. Serum insulin-like growth factor binding proteins (IGFBPs) as markers for anabolic/catabolic condition in fishes. Comp Biochem Physiol Part B Biochem Mol Biol. (2001) 129:229-36. doi: 10.1016/S1096-4959(01)00314-1

51. Shimizu M, Kishimoto K, Yamaguchi T, Nakano Y, Hara A, Dickhoff WW. Circulating salmon 28- and 22-kDa insulin-like growth factor binding proteins (IGFBPs) are co-orthologs of IGFBP-1. Gen Comp Endocrinol. (2011) 174:97-106. doi: 10.1016/j.ygcen.2011.08.005

52. Gabillard JC, Kamangar BB, Montserrat N. Coordinated regulation of the GH/IGF system genes during refeeding in rainbow trout (Oncorhynchus mykiss). J Endocrinol. (2006) 191:15-24. doi: 10.1677/joe.1.06869

53. Ren H, Yin P, Duan C. IGFBP-5 regulates muscle cell differentiation by binding to IGF-II and switching on the IGF-II auto-regulation loop. J Cell Biol. (2008) 182:979-91. doi: 10.1083/jcb.200712110

54. Martinek N, Shahab J, Sodek J, Ringuette M. Is SPARC an evolutionarity conserved collagen chaperone? J Dent Res. (2007) 86:296-305. doi: $10.1177 / 154405910708600402$

55. Neri M, Descalzi-Cancedda F, Cancedda R. Heat-shock response in cultured chick embryo chondrocytes. Eur J Biochem. (1992) 205:569-74. doi: 10.1111/j.1432-1033.1992.tb16814.x

56. Hoac B, Nelea V, Jiang W, Kaartinen MT, Mckee MD. Mineralizationinhibiting effects of transglutaminase-crosslinked polymeric osteopontin. Bone. (2017) 101:37-48. doi: 10.1016/j.bone.2017.04.007

57. Gericke A, Qin C, Spevak L, Fujimoto Y, Butler WT, Sørensen ES, et al. Importance of phosphorylation for osteopontin regulation of biomineralization. Calcif Tissue Int. (2005) 77:45-54. doi: 10.1007/s00223-004-1288-1

58. Johnston IA. Environment and plasticity of myogenesis in teleost fish. J Exp Biol. (2006) 209:2249-64. doi: 10.1242/jeb.02153

59. Zoladz JA, Koziel A, Broniarek I, Woyda-Ploszczyca AM, Ogrodna K, Majerczak J, et al. Effect of temperature on fatty acid metabolism in skeletal muscle mitochondria of untrained and endurance-trained rats. PLoS ONE. (2017) 12:e0189456. doi: 10.1371/journal.pone.0189456

60. Benedito-Palos L, Calduch-Giner JA, Ballester-Lozano GF, Pérez-Sánchez J. Effect of ration size on fillet fatty acid composition, phospholipid allostasis and mRNA expression patterns of lipid regulatory genes in gilthead sea bream (Sparus aurata). Br J Nutr. (2013) 109:1175-87. doi: 10.1017/S000711451200311X

61. Benedito-Palos L, Ballester-Lozano G, Pérez-Sánchez J. Wide-gene expression analysis of lipid-relevant genes in nutritionally challenged gilthead sea bream (Sparus aurata). Gene. (2014) 547:34-42. doi: 10.1016/j.gene.2014. 05.073

62. Ben-Zeev O, Hosseini M, Lai CM, Ehrhardt N, Wong H, Cefalù AB, et al. Lipase maturation factor 1 is required for endothelial lipase activity. J Lipid Res. (2011) 52:1162-9. doi: 10.1194/jlr.M011155

63. Qiang J, Tao Y-F, He J, Bao JW, Li HX, Shi W, et al. Influences of dietary lipid and temperature on growth, fat deposition and lipoprotein lipase expression in darkbarbel catfish (Pelteobagrus vachellii). J Therm Biol. (2017) 69:191-8. doi: 10.1016/j.jtherbio.2017.07.014

64. Kieffer J, Alsop D, Wood C. A respirometric analysis of fuel use during aerobic swimming at different temperatures in rainbow trout (Oncorhynchus mykiss). J Exp Biol. (1998) 201:3123-33.

65. Thibault M, Blier PU, Guderley H. Seasonal variation of muscle metabolic organization in rainbow trout (Oncorhynchus mykiss). Fish Physiol Biochem. (1997) 16:139-55. doi: 10.1007/BF00004671

66. Frøyland L, Lie $\varnothing$, Berge RK. Mitochondrial and peroxisomal $\beta$-oxidation capacities in various tissues from Atlantic salmon Salmo salar. Aquac Nutr. (2000) 6:85-9. doi: 10.1046/j.1365-2095.2000.00130.x

67. Nordgarden U, Torstensen BE, Frøyland L, Hansen T, Hemre G. Seasonally changing metabolism in Atlantic salmon (Salmo salar L.) II - $\beta$-oxidation capacity and fatty acid composition in muscle tissues and plasma lipoproteins. Aquac Nutr. (2003) 9:295-303. doi: 10.1046/j.1365-2095.2003.00260.x

68. Swida-Barteczka A, Woyda-Ploszczyca A, Sluse FE, Jarmuszkiewicz W. Uncoupling protein 1 inhibition by purine nucleotides is under the control of the endogenous ubiquinone redox state. Biochem J. (2009) 424:297-306. doi: 10.1042/BJ20091158

69. Jarmuszkiewicz W, Woyda-Ploszczyca A, Koziel A, Majerczak J, Zoladz JA. Temperature controls oxidative phosphorylation and reactive oxygen 
species production through uncoupling in rat skeletal muscle mitochondria. Free Radic Biol Med. (2015) 83:12-20. doi: 10.1016/j.freeradbiomed.2015. 02.012

70. Woyda-Ploszczyca AM, Jarmuszkiewicz W. The conserved regulation of mitochondrial uncoupling proteins: from unicellular eukaryotes to mammals. Biochim Biophys Acta Bioenerg. (2017) 1858:21-33. doi: 10.1016/j.bbabio.2016.10.003

71. Bermejo-Nogales A, Calduch-Giner JA, Pérez-Sánchez J. Tissue-specific gene expression and functional regulation of uncoupling protein 2 (UCP2) by hypoxia and nutrient availability in gilthead sea bream (Sparus aurata): implications on the physiological significance of UCP1-3 variants. Fish Physiol Biochem. (2014) 40:751-62. doi: 10.1007/s10695-013-9882-7
Conflict of Interest Statement: The authors declare that the research was conducted in the absence of any commercial or financial relationships that could be construed as a potential conflict of interest.

Copyright (ㄷ 2019 Balbuena-Pecino, Riera-Heredia, Vélez, Gutiérrez, Navarro, Riera-Codina and Capilla. This is an open-access article distributed under the terms of the Creative Commons Attribution License (CC BY). The use, distribution or reproduction in other forums is permitted, provided the original author(s) and the copyright owner(s) are credited and that the original publication in this journal is cited, in accordance with accepted academic practice. No use, distribution or reproduction is permitted which does not comply with these terms. 